\title{
Systemic Oppression and Rights of the Minorities: Discourse of the Reflections on Nigerian Society
}

\author{
Dr. Ernest Osas Ugiagbe \\ Department of Social Work, Faculty of Social Sciences \\ University of Benin, Benin City, Nigeria \\ Mrs. Helen E. Eweka \\ Department of Social Work, Faculty of Social Sciences \\ University of Benin, Benin City, Nigeria
}

Doi:10.5901/mjss.2014.v5n4p516

\begin{abstract}
Nigerian society is bedevilled by myriads of problems. Some of these problems are political, economic, and cultural and leadership failures in nature, while others have to do with the various relationships in the society and other societal processes, and the by-products of such dynamism of the modern society. This paper focuses on the problems and impact of systemic and institutional oppression in Nigerian society. The paper x-rays the nature, structure, dimension and spread of the various forms of oppressive forces and manifestations in Nigeria. The paper examines the overt and covert practices, policies and other sociocultural heritage of Nigerian people that enhances the domination and exploitations of some members of the Nigerian society by other privileged groups. These overt and covert practices are maximised by the three major ethnic nationalities and religious bigots amongst others who dominates other groups in all facets of human endeavours. The paper concludes by analysing the impact of systemic oppression on the people especially oppressed groups like the women, the aged, physically impaired and minorities and the implication of this unfortunate but avoidable social phenomenon on social policy development and Social Work practice in Nigeria.
\end{abstract}

Keywords: Systemic oppression, minority, ethno-religious, institutional, patriarchy

\section{Introduction}

Oppression, whether based on gender, race, class or ethno-religion takes place on multiple levels including the institutional (macro) intergroup (meso), and personal (micro) levels of social interactions. At all the three levels, structures and human agency are interactive, that is, structures constraint the choices and actions of individuals while individual choices and actions are at the same time determinant of the structures (Barone, 1998:2). Despite the plethora of intellectual insights and discourse on oppression in human society most of the writings have been on the traditional understanding of classism, racism and gender inequality. The major discourses tend to focus on the systemic oppression occasioned by class-struggle between the proletariat and bourgeoisie; between the white, coloured and black races and between the gender - male and female.

While credence can be given to the explicit of intellectual discourse on exploitation and dehumanization of class by another class or white exploitation of other races, there is the need to focus on systemic oppressions embedded in the day to day interactions between members of human society which has be historically taken for granted and daub as normal, acceptable and normative. An understanding of the personal and social dynamics of the society which breed oppression, dehumanization and degradation is imperative if a just and egalitarian society as envisioned by all is to established in our society. Oppressions are embedded in socio-cultural, political, economic and religions structures in human society. The situation is even more pathetic in the Nigerian society where tenets of culture, tradition and belief systems permeate every facet of human endeavour. The tenets of these cultures and traditions are however a source of subjugation of groups of people to the whims and caprices of other groups of people within the Nigerian society.

The justification for the oppression of women, children, the aged and the physically challenged, for example, are in the tenets of social, cultural and other systemic structures in human society. While such systemic processes are taken for granted and as normal, they however breed oppression in all ramifications. This paper attempts to structurally locate 
oppression in system, structures and societal processes and how these affect the psyche of Nigerians. The paper is particularly interested in the subtle means of domination in the political arena of Nigeria. It will also attempt an elucidation of human agency constrained by the macro and meso level structures of the society while at the same time determine as well as transform the human actors of such societal processes to become either dominant an oppressive or subdued and subservient.

\section{Conceptual Clarification of Oppression in Human Society}

Oppression can be defined as the systematic, institutionalised mistreatment of one group of people by another for whatever reason (Yamato, 1995:66). Webster's Third International Dictionary (2007), defines oppression as 'unjust or cruel exercise of authority or power especially by the imposition of burdens; the condition of being weighed down; an act of pressing down; a sense of heaviness or obstruction in the body or mind. Social work dictionary (2003) defines oppression as "the social act of placing severe restrictions on an individual, a group or institution'. Typically, a government or groups or political organization that is in power places these restrictions formally or covertly on oppressed groups so that they may be exploited and less able to compete with other social groups. The oppressed individual or group is devalued, exploited and deprived of privileges by the individual or group which has more power and privileges in the context of the realities of the society (Barker, 2003).

Social oppression according to Blackwell Dictionary of Sociology is "a concept that describes a relationship between groups or categories of between groups or categories of people in which a dominant group benefits from the systematic abuse, exploitation, and injustice directed toward subordinate group." According to Johnson (2000), relationship between groups and relationships between groups and social categories should not be confused with the oppressive behaviour of an arrogant and proud individual. While the behaviour of the arrogant individual may affect a few, on the other hand, social oppression affects the generality of the people. A man may not himself actively participate in oppressive behaviour directed at women for example, but he nonetheless benefits from the general oppression of women. In this sense, all members of dominant and subordinate categories participate in social oppression regardless of their individual attitude or behaviour. Social oppressions are usually institutionalized because they are usually entrenched and enforced in all facets of human endeavour that they are not easily identified as oppression and do not appear to be conscious prejudicial inclinations or overt manifestations of discrimination. That is, the crux of this paper: to identify the covert, subtle and often-taken-for granted systemic structures and actions of super ordinate and subordinate groups in the Nigerian society but which none the less result in complexes in the behaviours of the oppressed.

Similarly, Charton (1998) writes that oppression occurs when individuals are systematically subjected to political, economic, cultural, or social degradation because they belong to a social group and intense, enduring and close proximal interactions result from structures of domination and subordination, and correspondingly, ideologies of superiority and inferiority becomes the by products of such associations. For every social category that is privileged, one or more other categories are oppressed in relation to it. The concept of oppression points to social forces that tend to press upon people and hold them down, to hem them in and block their pursuits of a good life. Just as privilege tends to open doors of opportunity, oppression tends to slam them shut (Johnson, 2000).

Elaborating more on the concept of oppression, Deutsch (2006) posited that oppression is the experience of repeated, widespread, systemic injustice. It needs not be extreme, repressive and involving the legal system (as in slavery, apartheid, or the lack of right to vote) nor violent (as in tyrannical societies). The modern and more perverse and deep seated oppressions of modem day society are what Havey (1999) referred to as "civilised oppressions" which are embedded in unquestioned and taken-for-granted norms, habits, and symbols which characterise the assumptions underlying institutions and rules, and the collective consequences of following and subordinating to those who rules." Oppression refers to the vast and deep injustices some groups suffer as a consequence of often unconscious assumptions and reactions of well-meaning people in ordinary interactions that are supported by the media and cultural stereotypes as well as by the structural features of bureaucratic hierarchies and other socio-economic mechanisms (Young, 1990).

Oppression is evil and refers to relations of domination and exploitation-economic, social and psychological between individuals; between social groups and classes within and beyond societies; and globally between entire societies like the Northern hemisphere oppressing the Southern hemisphere. Oppression breeds injustice which is discriminatory, dehumanizing and development-inhibiting conditions of living like unemployment, poverty, homelessness and lack of health care, imposed by oppressors upon dominated and exploited individuals, social groups, classes, gender and peoples". Oppression seems motivated by intent to exploit (i.e. benefit disproportionately from the resources, 
capacities and productivity of others) and it results typically in disadvantageous, unjust conditions of living for its victims. It serves as a means to enforce exploitation toward the goal of securing advantageous conditions of living for its perpetrators (Gil, 1994). Oppression manifests in form of sexism, heterosexism, homophobia, ageism/adultism, ableism, racism, classism and ethno-religionist. It is expressed, for example, in gender boxes like 'be a man' / act like a lady (Gil, 1994).

\section{The Five Faces of Oppression}

According to Young (2004), in its traditional usage, oppression means the exercise of tyranny by a ruling group (men, class, race, ethnic), which creates injustice in other circumstances as well. However, it is not only cruel tyrant with bad intentions that oppresses people; a well-intentioned liberal society can place system-wide constraints on groups and limit their freedom, choices and liberty. This could mean denying people language, education and other opportunities that might make them become fully human in both mind and body. For example the imposition of Hausa, Yoruba and Ibo languages on other ethnic groups in Nigeria. The Hausa language for example is more or less the official language of the Nigerian armed forces. Other non-Hausa speaking Nigerians in the armed forces must speak the language or face the wrath and losses appertaining thereto. The imposition of the so-called major languages on other Nigerians especially in the Federal Government Colleges is a systemic oppression (Davis, 1990).

According to Young (2004), there are five faces or types of oppression: violence, exploitation, marginalization, powerlessness and cultural imperialism.

Exploitation is the act of using peoples' labour or resources to produce profit while not compensating them fairly. Exploitative people usually justify their actions in the name of law, constitutions, national policy/unity and capitalism. Capitalism creates 'haves' (those that have wealth) and 'have-nots' (those that do not have wealth). Exploitation creates a system that perpetuates class differences, keeping the rich richer and the poor poorer. (Clarice,1992).

Marginalization: This refers to the act of relegating or confining a group of people to a lower social standing or outer limit or edge of society. This is a systemic process of exclusion of some people from certain opportunities, privileges and rights. Marginalization is worse than exploitation because society has decided that it cannot or will not use or allow some people or group for labour or leadership roles.

Powerlessness is linked to Marx theory of socialism and is a situation whereby the ruling class or dominant group lords it over others who are situated to take orders and rarely have the right to do otherwise. Some of the fundamental injustices associated with powerlessness are inhibition to develop one's capacity, lack of decision making power, and exposure to disrespectful treatment because of the lowered status (Karen, 1991).

Cultural imperialism involves taking the culture of the ruling class and establishing it as the norm. The dominant groups that have power in society control how the people in that society interpret and communicate. The beliefs of that society are the most widely disseminated and expressed the experience, values, goals and achievements of the dominant groups like the Hausa/Fulani cultural imperialism in Northern Nigeria.

Violence is perhaps the most obvious and visible form of oppression. Members of the dominant groups live with the knowledge that they must randomly inflict unprovoked attacks on their persons or property. These attacks do not necessarily need a motive but are intended to damage, humiliate or destroy the person (www.accessalliance.ca).

\section{Institutionalized Oppression}

According to Cheney et al (2006), institutions are fairly stable social arrangements and practices through which collective actions are taken. Good examples of such institutions are legal, educational, health, political/polity, family, social services, media and criminal justice systems amongst others. Institutional oppression is the systematic mistreatment of people within a social identity group, supported and enforced by the society and its institutions solely based on the person's membership in the social identity group. Institutional oppression occurs when established laws, customs, and practices systematically reflect and produce inequities based on one's membership in targeted social identity groups (Kathleen, 1990).

Institutional oppression creates a system of invisible barriers limiting people based on their membership of unfavoured social identity groups. The barriers are only invisible to those 'seemingly' unaffected by them (Cheney et al 2006). The practice of institutionalized oppressed is based on the belief in inherent superiority or inferiority and is a matter of result regardless of intent (Kathleen, 1990). Institutionalized oppressions are very common in African nations, the Middle East and other Third World nations but less pronounced in developed nations. 


\section{Systemic Oppression Theory}

In society, oppression operates on three levels at all time: on a personal level ('p'), on a cultural level ('c'), and on a structural level ('s'). Oppression at the personal level ('p') comprises the thoughts, attitudes, and behaviours that depict a negative (pre) judgement of a particular subordinate social group. It is usually based on stereotypes and may be overt or covert. Government officials in Nigeria may stigmatise a protester as an agent of opposition or disgruntled elements (Davis, 2002). A good example is the way Academic Staff Union of Universities (ASUU) incessant strikes are taken by Nigerians as political and the members daub as agents of opposition despite the genuineness of ASUU demands and intentions.

Oppression at the cultural level ('c') consists of the values, norms, and shared patterns of seeing, thinking, and getting along with an assumed consensus about what is right and normal that taken together endorse the belief in a superior culture. It refers to the ways and discursive practice used by the dominant group to portray subordinate groups in history - literature, the media, stories, movie, humour, stereotypes and especially mass or popular culture. It acts as a vehicle for transmitting and presenting the dominant culture as the norm, the message being that everyone should conform to it. In Nigeria this has resulted in ethnocentric imperialism and cultural imposition. It is the cement of cultural oppression that reinforces personal and structural oppression. For example, the so-called major ethnic groups through state and organizational structures transmit ideas that their ways of life are the best (Bell, 1994).

Oppression at the structural level ('s') refers to the means by which oppression is institutionalized in society through what is called mitigating social structures like religion, government, education, law, the media and health care system. These institutions work together primarily in favour of the dominant group at the expense of subordinate group. The oppressions at this level are often given their formal sanctioning through government, education, law, religion, the media and other social structures (www.stage.left.org).

See table 1 and figure 1

Table 1: The Difference between Privileged Groups and Oppressed Groups in Society

\begin{tabular}{|c|c|l|}
\hline Social Group & Privilege & \multicolumn{1}{c|}{ Oppressed } \\
\hline Age & Adults (18-64) & Children and elders \\
\hline Ability & $\begin{array}{c}\text { People without } \\
\text { impairment }\end{array}$ & People with impairment \\
\hline Religion & Christianity & $\begin{array}{l}\text { Buddhism, Hinduism, Islam, Baha'i, paganism, Taoism, Athens, Rastafarians, Sikhism, } \\
\text { Judaism }\end{array}$ \\
\hline Ethnicity & Europeans, Arabs & People of colour \\
\hline Social class & $\begin{array}{c}\text { Upper class, middle } \\
\text { class }\end{array}$ & Poor and working class \\
\hline $\begin{array}{c}\text { Sexual } \\
\text { orientation }\end{array}$ & Heterosexual & Lesbian, Gay Bisexual, two-spirited Queer, Questioning \\
\hline Language & English & Other than English \\
\hline $\begin{array}{c}\text { Indigenous } \\
\text { culture }\end{array}$ & Son of the soil & $\begin{array}{l}\text { Settlers, Sabon-geri (areas in northern Nigeria cities which separate indigenes from } \\
\text { southerners) }\end{array}$ \\
\hline Gender & Male & Female, intersexed, transgendered, gender queer \\
\hline
\end{tabular}

Source: Stage Left Production Workshop for Canada World Youth, Oppression and Privilege Framework. www.left.org.

Figure 1: Triangle of Oppression Theory

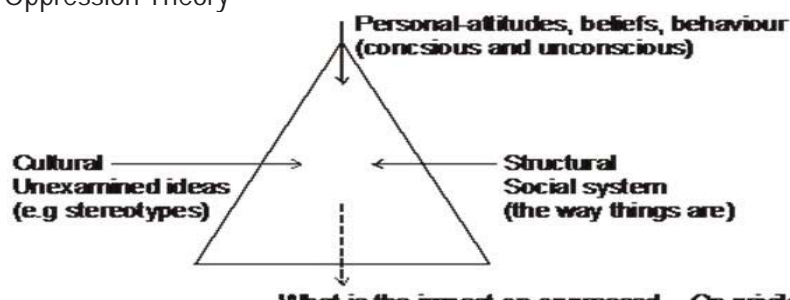

Source: Jamie Percy-Smith (2000)

What is the irrpact on oppressed... On privilege people. 


\section{Systemic Oppression: Nigerian Society in Perspective}

Systemic oppression is endemic perverse and strictly entrenched in all aspects of societal processes in Nigeria. In culture, religion, polity, law, social and economic segments in Nigerian society all help in oppression of some groups by others. The systemic oppressions and the impact will be examined in the ways they affect women, the aged physically challenged, the minority and children.

Systemic oppression in Nigeria comes in the form of social exclusion, subtle and overt oppression policies, programmes and practices. Social exclusion refers to disadvantages in relation to certain norms of social, economic or political activity pertaining to individuals, households, spatial areas or population groups; the social, economic and institutional processes through which disadvantage comes about; and the outcomes or consequences for individual, groups or communities. The European Commission defines social exclusion thus:

Social exclusion refers to the multiple and changing factors resulting in people being excluded from the normal exchanges, practices and rights of modern society. Poverty is one of the most obvious factors, but social exclusion also refers to inadequate rights in housing, education, health and access to services. It affects individual and groups, particularly in urban and rural areas, who are in some way subject to discrimination or segregation; and it emphasizes the weaknesses in the social infrastructure and the risk of allowing a two-tier society to become established by default. The Commission believes that a fatalistic acceptance of social exclusion must be rejected and that all community citizens have right to the respect of human dignity. (Commission of the European Communities, 1993:1).

Figure 2: Social exclusion in context

Source: Jamie Pearce-Smith (2000)

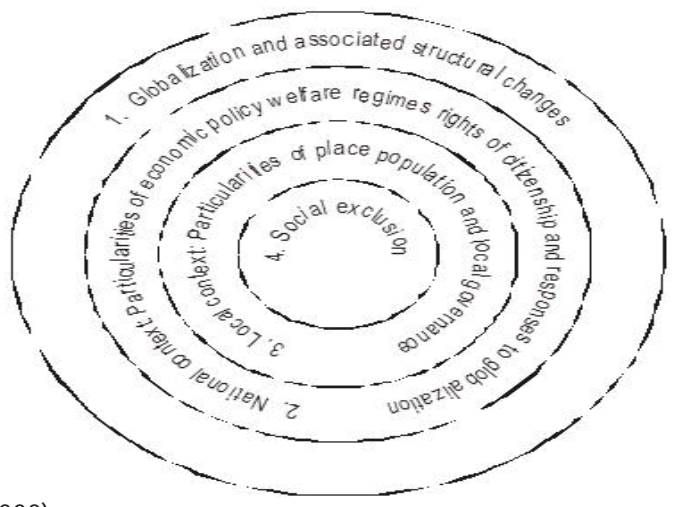

The most obvious manifestation of systemic oppression in Nigeria is social exclusion of women, the aged, physically impaired, children and minority from all spheres of national development and human endeavour. This is because social exclusion and systemic oppression which is its aftermath is occasioned by process or set of processes rather than a static condition, and it is necessarily a relational concept and structural. Thus:

Structural processes affect the whole of society in ways which creates barriers which prevent particular groups from forming those kinds of social relationships with other groups which are essential to realizing a full human potential. It is not that some groups exclude other groups, but that processes affecting the whole of society mean that some groups experience social boundaries as barriers preventing their full participation in the social boundaries as barrier preventing their full participation in the economic, political and cultural life of the society within which they live.(Madanipour, et al, 1998:17)

The systemic oppression in Nigeria affects women, the aged, physically impaired, children and the minority in economic, social, political, neighbourhood, individual spatial and groups' dimensions.

\section{Economic Dimension:}

Systemic oppression in the economic dimension in Nigeria manifests in economic arena such as employment, human capital indicators, access to fund and economic participation and empowerment. There is no gainsaying the fact that women, the aged, physically impaired and minority suffer economic hardship in forms of unemployment, exclusion and 
lack of access to economic power - enhancing facilities in the country. There are evidence that these groups of people suffer long term unemployment and job insecurity, poverty and deprivation. For example, women have been oppressed over the years in the area of employment and economic power as the report below shows. By virtue of the population of Nigeria, the potential female labour force is $50 \%$ but the actual value is $31 \%$. The proportion of women in the formal sector is very minimal. This is noticeable in the industries and the civil service; statistics indicate that in the federal and state civil service in the country women are in majority in the very junior cadres (Ajir, 2002). See figure 3, table 2 and 3

Fig 3: Percentage Distribution of Employment in Non-Agricultural Sector by Gender - 2007 (National)

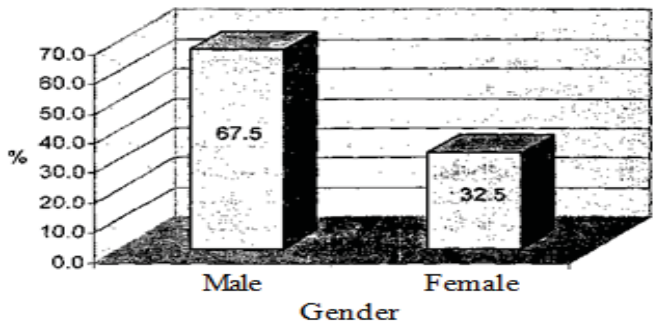

Source: National Bureau of Statistics, 2009, Women and Men in Nigeria Final Report

Table 2: Gender Gaps in Labour Force Participation and Earned Income, 2010

\begin{tabular}{|c|c|c|c|c|c|c|}
\hline & \multicolumn{3}{|c|}{ Labour Force Participation } & \multicolumn{3}{c|}{ Estimated Earned Income (US\$) } \\
\hline Year & Female & Male & F/M Ratio & Female & Male & F/M Ratio \\
\hline 2010 & 45 & 85 & 0.53 & 1,163 & 2,777 & 0.42 \\
\hline 2009 & 47 & 86 & 0.54 & 1,054 & 2,650 & 0.40 \\
\hline 2008 & 47 & 86 & 0.54 & 652 & 1,592 & 0.41 \\
\hline 2007 & 39 & 72 & 0.55 & 669 & 1,628 & 0.41 \\
\hline 2006 & 40 & 75 & 0.53 & 614 & 1,495 & 0.41 \\
\hline
\end{tabular}

Source: World Economic Forum, Global Gender Gap Index 2010 Nigeria Profile

Table 3: Gender Gaps in Access to Economic Resources

\begin{tabular}{|l|c|c|}
\hline \multicolumn{1}{|c|}{ Access to resource } & Female & Male \\
\hline Credit facility & 45.7 & 54.3 \\
\hline Bank loan & 21.9 & 78.3 \\
\hline Microcredit & 27.9 & 72.1 \\
\hline Grants & 28 & 72 \\
\hline Esusu & 55.7 & 44.3 \\
\hline Cooperative loan & 34.7 & 65.3 \\
\hline Farmland & 35.9 & 64.1 \\
\hline Agricultural inputs & 26.7 & 73.3 \\
\hline Agricultural extension services & 22.8 & 77.2 \\
\hline Storage facility & 26 & 74 \\
\hline Own land & 15.8 & 84.2 \\
\hline
\end{tabular}

Source: UNDP, 2009, Nigeria Human Development Report 2008-2009, p.53

The worst hit by the economic exclusion are the physically impaired and the aged. The impaired are hardly employed in Nigeria and the aged as oppressed by the slogan of ableism and stigmatisation of the aged as "old skool" spent "forces" and 'fired' 'senior citizens' who are treated with levity by the younger generation power wielders. The aged are so powerless in Nigeria to the extent that live on the fringe of the societal processes and hence are rarely seen and heard off.

\section{Socio-Political:}

The systemic oppression of the women, the aged and physically impaired including children and minority is perhaps most evident in social and political circles in Nigeria. Socially, women are marginalized and oppressed in all ramifications - 
family, household, community and society. The patriarchal Nigerian society enhances and exercabate the oppression and dehumanisation of women and other marginalised members of the society. The social exclusion and systemic oppression are evident in indicators like education, right violation and political participation and leadership roles. In the social arena, women are not given opportunity to lead or even participate in the societal processes rather they are regarded and are actually passive observers and receivers of crumbs from the masters' (male) tables. The educational enrolment of girl child in schools, the political and leadership positions held by women and the marginal power relations of male and females on Nigeria as evident in the data in table 3 are pointers to the position taken in this paper. Table 4 and 5

Table 4: Seats Held in National Assembly by Year of Election and Gender

\begin{tabular}{|c|c|c|c|c|c|c|c|c|}
\hline & \multicolumn{2}{|c|}{1999} & \multicolumn{2}{c|}{2003} & \multicolumn{2}{c|}{2007} & \multicolumn{2}{|c|}{2011} \\
\hline Senate & Number & $\%$ & Number & $\%$ & Number & $\%$ & Number & $\%$ \\
\hline Men & 106 & 97.3 & 105 & 96.3 & 100 & 91.7 & 102 & 93.6 \\
\hline Women & 3 & 2.8 & 4 & 3.7 & 9 & 8.3 & 7 & 6.4 \\
\hline Total & 109 & 100.0 & 109 & 100.0 & 109 & 100.0 & 109 & 100.0 \\
\hline \multicolumn{8}{|c|}{ House of Reps } \\
\hline Men & 348 & 96.7 & 338 & 93.9 & 334 & 92.8 & 339 & 94.2 \\
\hline Women & 12 & 3.3 & 22 & 6.1 & 26 & 7.2 & 21 & 5.8 \\
\hline Total & 360 & 100.0 & 360 & 100.0 & 360 & 100.0 & 360 & 100.0 \\
\hline \multicolumn{8}{|c|}{ Both houses } \\
\hline Men & 454 & 96.8 & 443 & 94.46 & 434 & 92.5 & 441 & 94.0 \\
\hline Women & 15 & 3.2 & 26 & 5.54 & 35 & 7.5 & 28 & 6.0 \\
\hline Total & 469 & 100.0 & 469 & 100.0 & 469 & 100.0 & 469 & 100.0 \\
\hline
\end{tabular}

Source: NBS, 2009, and National Centre for Women Development.

Table 5: Comparison of women representation in 2003, 2007 and 2011 general elections

\begin{tabular}{|l|c|c|c|c|}
\hline \multicolumn{1}{|c|}{ Position } & $\begin{array}{c}\text { No. of available } \\
\text { seats }\end{array}$ & $\begin{array}{c}\text { No. of women } \\
\text { elected in 2003 }\end{array}$ & $\begin{array}{c}\text { No. of women } \\
\text { elected in 2007 }\end{array}$ & $\begin{array}{c}\text { No. of women } \\
\text { elected in 2011 }\end{array}$ \\
\hline Presidency & 1 & 0 & 0 & 0 \\
\hline Senate & 109 & $3(2.27 \%)$ & $9(8.26 \%)$ & $8(7.34 \%)$ \\
\hline House of Representatives & 360 & $21(5.83 \%)$ & $25(6.94 \%)$ & $12(3.33 \%)$ \\
\hline Governorship & 36 & 0 & 0 & 0 \\
\hline
\end{tabular}

Source: Gender Audit and IPU PARLINE database, 2012.

The patriarchy is one of the instruments of systemic oppression in Nigeria. Patriarchy according to Roc (1977), "is a familial-social, ideological political system in which men by force, direct pressure or through ritual, tradition law and language. Custom etiquette, education and the division of labour, determine what part women shall or shall not play in which the female is everywhere subsumed under the male". The effects of patriarchy include but not limited to women low self esteem and lack of confidence hence their under representation in political institutions. The oppression of women also manifest in maternal deaths in Nigeria because of the lip service paid to issues that concerns women by the male dominated Governments. According to Ezechukwu (2000), Nigeria has more than 300 ethnic groups speaking 250 languages and 1,000 dialects. Maternal mortality ratio in Nigeria is estimated at 800 maternal deaths per 100,000 live births. With a wide geographical disparity ranging from 166 per 100,000 live births in the south to 154 per 100,000 live births in the North, of the estimated 536,000 maternal deaths that occur globally, Nigeria contributes approximately $10 \%$, although its population size is only about $2 \%$ of the global population figure. Nigeria has the second highest maternal mortality burden in the world with estimated 37,000 mothers dying annually from pregnancy related causes. Thus most maternal deaths result not from disease per se but from pregnancy-related complications, which are now widely recognised as a leading cause of death and disability among women of reproductive age in developing countries. An estimated $40 \%$ of pregnant women experience pregnancy-related death problems during or after pregnancy and child birth (Nigeria Demographic and Health Survey, 2003). See Okojie (2011).

\section{Ethno-Religious Oppression in Nigeria}

There is nothing wrong with ethnicity. It can make and create avenues for healthy competition in economic development, and growth, as it did in times past. It can be used to enhance the fair and even distribution of the gains of good 
governance (Udegbe, 2013). But in Nigeria the problem lies not in the nature of ethnicity, but in the minds and heart of those who use and abuse ethnicity for their own selfish gains. Ethnicity has been used as an instrument of oppression of the minority in Nigeria. The federal civil service of Nigeria is dominated by the three major ethnic groups - Hausa, Yoruba and Ibo, eight of every ten federal senior civil servant come from the three groups. The principal officers in the armed forces, police and other Federal parastatals are mainly occupied by the "major" ethnic groups. In politics and other aspirations, Nigerian of minority groups can only dream of becoming at most second best i.e. Vice President, Deputy Speaker of the House of Representatives, etc. while an average Hausa, Yoruba and Ibo can dream of becoming the President of Nigeria and we will surely attain it.

Ethno-religious oppression is silently being revolutionized in Nigeria. At the national level the Muslims and Christians are dominants in all spheres of human endeavour. Under the guise of religion, the veil has become a tool of invisibility and spatial control. The veil is one spill-over result of Sharia that affects Christian women as well and this has facilitated the acts of violence against people who do not wear the hijab. Men are given the opportunity to judge morality in women as Christian, Muslims or pagans within a Federal Government that is supposed to be secular (Little, 2011).

Ethno-religious oppression and conflicts refer to a situation in which the relationship between members of one ethnic or religious group and another of such group in a multi religious society is characterised by lack of cordiality, mutual suspicions, fear and the tendency towards violent attack or confrontation. Several visible causes of religious violence in Nigeria have been identified in the literature (Agwu, 2009; Gofwen, 2004; Salawu, 2010; Iwaro, 2006; Kwaja, 2009; Omotosho, 2003; Sanusi, 2009; Onuaha, 2010). Most of the authors cited above emphasised socio-political, economic factors and governance as the remote and immediate causes. None of the literature examines oppression as the main causal factor of ethno-religious violence.

Oppression, domination, exploitation, victimisation, discrimination and marginalisation are all the underlying factors of ethno-religious violence in Nigeria. The victims are usually the weaker groups. Hausa/Fulani vs Igbos, Muslim vs Christians in the North, Muslims Fulani vs natives of Jos, Kala-Kato sect vs Christians in Bauchi and so on. In the table of cases of ethno-religious violence in Nigeria 1999-2012, shown in figure 1, a critical analysis of the violence reveals that the violence were precipitated by oppressive and exploitative forces within the Nigerian societal system under the guise of religious intolerance and provocation. See Table 1

Table 6: Some cases of religious violence in Nigeria, 1999-2012

\begin{tabular}{|c|c|c|c|c|}
\hline No. & Date & State(s) & Nature & Remarks \\
\hline 1. & 1 Jul. 1999 & Ogun & $\begin{array}{l}\text { Violent clashes between Yoruba traditional worshippers and } \\
\text { Hausa groups in Sagamu, Ondo state. }\end{array}$ & $\begin{array}{l}\text { The crisis originated from the killing of a Hausa woman by the } \\
\text { Oro Masqueraders for violating traditional rites. }\end{array}$ \\
\hline 2. & $\begin{array}{c}22 \text { Jul. } \\
1999\end{array}$ & Kano & Reprisal to the Sagamu crisis above. & The casualty figure was not reported. \\
\hline 3. & $\begin{array}{l}20 \text { Dec. } \\
1999\end{array}$ & Kwara & $\begin{array}{l}\text { Muslim fundamentalists attacked and destroyed over } 14 \\
\text { churches in Ilorin. }\end{array}$ & $\begin{array}{l}\text { Properties worth several millions of naira were destroyed and an } \\
\text { unspecified casualty reported. }\end{array}$ \\
\hline 4. & $\begin{array}{c}21-22 \\
\text { Feb.2000 }\end{array}$ & Kaduna & Riots over the introduction of Sharia. & An estimated 3000 people died. \\
\hline 5. & $\begin{array}{c}28 \text { Feb. } \\
2000\end{array}$ & Abia & Religious riots in Aba, and minor disturbances in Umuahia. & $\begin{array}{l}\text { Over } 450 \text { persons killed in Aba, Abia state, as reprisal for the } \\
\text { Kaduna crisis. }\end{array}$ \\
\hline 6. & $\begin{array}{c}8 \text { Sept. } \\
2000\end{array}$ & Gombe & The Kaltungo religious crisis. & The crisis erupted over the implementation of Sharia in the state. \\
\hline 7. & $\begin{array}{l}12 \text { Oct. } \\
2001\end{array}$ & Kano & Religious riot in Kano. & $\begin{array}{l}\text { In protest to US invasion of } \\
\text { Afghanistan over Osama bin Laden. Over } 150 \text { persons were } \\
\text { killed. }\end{array}$ \\
\hline 8. & $\begin{array}{c}7-17 \\
\text { Sept.2001 }\end{array}$ & Jos & $\begin{array}{l}\text { A religious riot between Muslims and Christians in Jos. } \\
\text { Mosques, churches and several properties were damaged or } \\
\text { torched. The clashes started on September } 7 \text { and lasted } \\
\text { nearly two weeks, ending on September } 17 .\end{array}$ & $\begin{array}{l}\text { The riot broke out when the Islamic Brigade attacked a Christian } \\
\text { woman who attempted to cross a public high-way barricaded by } \\
\text { Muslim worshippers on Friday. Over } 300 \text { people were killed. }\end{array}$ \\
\hline 9. & $\begin{array}{l}16 \text { Nov. } \\
2002\end{array}$ & Kaduna & $\begin{array}{l}\text { The Miss World crisis in which Muslims attacked Christians } \\
\text { and churches }\end{array}$ & $\begin{array}{l}\text { The crisis was triggered by an article authored by Isioma Daniel } \\
\text { in This Day newspaper, alleging that Prophet Mohammed would } \\
\text { have loved to have the girls. Over } 250 \text { people were killed and } \\
\text { several churches destroyed. }\end{array}$ \\
\hline 10. & $\begin{array}{l}8 \text { Jun. } \\
2004\end{array}$ & Adamawa & $\begin{array}{l}\text { Religious conflict between Christians and Muslims in Numan } \\
\text { town. }\end{array}$ & $\begin{array}{l}\text { Caused by the location of the town's Central Mosque close to } \\
\text { Bachama paramount ruler's palace. Over } 17 \text { persons killed. }\end{array}$ \\
\hline 11. & $\begin{array}{l}18 \text { Feb. } \\
2006\end{array}$ & Borno & $\begin{array}{l}\text { Religious conflict between Christians and Muslims in } \\
\text { Maiduguri. }\end{array}$ & $\begin{array}{l}\text { The riot was caused by the Danish cartoon on Prophet } \\
\text { Mohammed, in Jyllands-Posten newspaper. Over } 50 \text { persons } \\
\text { killed and } 30 \text { churches destroyed; over } 200 \text { shops, } 50 \text { houses } \\
\text { and } 100 \text { vehicles vandalised. }\end{array}$ \\
\hline 12. & 22 Mar. & Gombe & Muslim pupils killed their Christian teacher, Mrs Oluwatoyin & The pupils claimed that their teacher desecrated the Qur'an while \\
\hline
\end{tabular}




\begin{tabular}{|c|c|c|c|c|}
\hline & 2007 & & Olusesan. & attempting to stop a student from cheating in an examination hall. \\
\hline 13. & $\begin{array}{c}28 \text { Nov. } \\
2008\end{array}$ & Plateau & $\begin{array}{l}\text { Religious violence between Muslims and Christians in the city } \\
\text { of Jos. }\end{array}$ & $\begin{array}{l}\text { The crisis which was triggered by the controversial results of a } \\
\text { local election later turned religious. Over } 700 \text { people killed and } \\
\text { thousands internally displaced. }\end{array}$ \\
\hline 14. & $\begin{array}{c}21 \mathrm{Feb} . \\
2009\end{array}$ & Bauchi & Ethno-religious conflict at the Makama New Extension. & $\begin{array}{l}\text { Over } 11 \text { people were killed, more than } 400 \text { houses burnt, and } \\
\text { over } 1600 \text { families displaced. }\end{array}$ \\
\hline 15. & $\begin{array}{c}26-30 \mathrm{Jul} \\
2009\end{array}$ & $\begin{array}{l}\text { Bauchi, } \\
\text { Borno, } \\
\text { Kano, } \\
\text { Yobe } \\
\end{array}$ & $\begin{array}{l}\text { Religious violence unleashed by the radical Boko Haram sect } \\
\text { on Christians. }\end{array}$ & $\begin{array}{l}\text { Over } 700 \text { persons killed, } 3500 \text { persons internally displaced, } \\
1264 \text { children orphaned, over } 392 \text { women widowed, and several } \\
\text { properties destroyed. }\end{array}$ \\
\hline 16. & $\begin{array}{c}29 \text { Dec. } \\
2009\end{array}$ & Bauchi & $\begin{array}{l}\text { Religious violence unleashed by the Kala-Kato sect on } \\
\text { Christians. }\end{array}$ & $\begin{array}{l}\text { Over } 38 \text { persons killed; about } 20 \text { suspected members of the sect } \\
\text { arrested; and over } 1000 \text { people internally displaced. }\end{array}$ \\
\hline 17. & $\begin{array}{c}17-20 \text { Jan. } \\
2009\end{array}$ & Plateau & Resurgence of religious crisis in Jos. & $\begin{array}{l}\text { Police announced at least } 320 \text { killed, but aid workers and local } \\
\text { leaders place death toll at over } 550 \text {. Over } 40000 \text { persons } \\
\text { displaced. }\end{array}$ \\
\hline 18. & $\begin{array}{l}7 \text { Mar. } \\
2010\end{array}$ & Plateau & $\begin{array}{l}\text { Attacks by Fulani Moslems on Christian-dominated villages of } \\
\text { Dogo Nahawa, Shen and Fan in Jos. }\end{array}$ & Over 500 people - mainly women and children - were killed. \\
\hline 19. & $\begin{array}{c}17 \text { Mar. } \\
2010\end{array}$ & Plateau & $\begin{array}{l}\text { Suspected Fulani militia men attacked residents of Biye and } \\
\text { Batem in Jos. }\end{array}$ & 13 persons killed. \\
\hline 20. & $\begin{array}{c}11 \mathrm{Apr} \\
2010\end{array}$ & Plateau & $\begin{array}{l}\text { Attack on a Christian village of Berom stock, some } 30 \\
\text { kilometres south of Jos, by suspected Fulani herdsmen. }\end{array}$ & $\begin{array}{l}\text { The attackers targeted the homes of some officials in Kura Jenta, } \\
\text { in reprisal to the killing of about } 150 \text { Fulani Muslims, who were } \\
\text { allegedly killed and dumped in wells on } 19 \text { January 2010. No life } \\
\text { was lost but } 3 \text { houses and } 6 \text { vehicles were torched. This violence } \\
\text { was ethno-religious. }\end{array}$ \\
\hline 21. & $\begin{array}{c}22 \text { May } \\
2010\end{array}$ & Plateau & $\begin{array}{l}\text { Murder of three (Muslim) Fulani herdsm } \\
\text { in Barkin Ladi Local Government, Plate }\end{array}$ & $\begin{array}{l}\text { The attackers were alleged to be Berom Christian youths. It was } \\
\text { ethno-religious. }\end{array}$ \\
\hline 22. & $\begin{array}{c}22 \text { May } \\
2010\end{array}$ & Plateau & $\begin{array}{l}\text { Attack on some Christians, who were returning from their } \\
\text { place of worship along Bauchi road in Jos. }\end{array}$ & $\begin{array}{l}\text { Reprisal attack by Muslims over the killing of } 3 \text { Fulani Muslims. At } \\
\text { least } 1 \text { person died while many were injured. }\end{array}$ \\
\hline 23. & $\begin{array}{l}17 \mathrm{Jul} \\
2010\end{array}$ & Plateau & $\begin{array}{l}\text { Muslim Fulani herdsmen launched an overnight attack on a } \\
\text { Christian village, Mazah, north of the city of Jos. }\end{array}$ & $\begin{array}{l}\text { About eight people were reportedly killed, including the wife, two } \\
\text { children and a grandson of a Pastor. Seven houses and a church } \\
\text { were also burned during the attack. }\end{array}$ \\
\hline 24. & $\begin{array}{c}29 \text { Aug. } \\
2011\end{array}$ & Plateau & $\begin{array}{l}\text { Clashes between Muslims and Christians at Rukuba road and } \\
\text { Farin Gada in Jos during the Ramadan prayers. }\end{array}$ & $\begin{array}{l}\text { No less than } 20 \text { persons were killed, } 50 \text { injured, over } 50 \text { motor } \\
\text { vehicles and } 100 \text { motor cycles were torched. }\end{array}$ \\
\hline 25. & $\begin{array}{c}16 \text { Jun. } \\
2011\end{array}$ & $\begin{array}{c}\text { Police } \\
\text { Head- } \\
\text { quarters, } \\
\text { Abuja }\end{array}$ & $\begin{array}{l}\text { Suicide bomb attack at the Police Headquarters, Abuja by } \\
\text { suspected Boko Haram Islamists whose ideology is framed } \\
\text { around religious extremism (Wahabism). }\end{array}$ & Authorities said 6 persons were killed and 73 vehicles destroyed. \\
\hline 26. & $\begin{array}{l}26 \text { Aug. } \\
2011\end{array}$ & $\begin{array}{l}\text { UN } \\
\text { House, } \\
\text { Abuja }\end{array}$ & $\begin{array}{l}\text { Suicide bombing at the UN House, Abuja by suspected Boko } \\
\text { Haram Islamists. }\end{array}$ & $\begin{array}{l}23 \text { persons (11 UN personnel and } 12 \text { non-UN personnel) were } \\
\text { killed. }\end{array}$ \\
\hline 27. & $\begin{array}{l}5 \text { Nov. } \\
2011\end{array}$ & $\begin{array}{l}\text { Potiskum, } \\
\text { Damaturu } \\
\text { and } \\
\text { Maiduguri }\end{array}$ & $\begin{array}{l}\text { Coordinated attacks on churches and police stations by } \\
\text { suspected } \\
\text { Boko Haram Islamists. }\end{array}$ & $\begin{array}{l}\text { More than } 90 \text { persons were reportedly killed, several churches } \\
\text { and police stations torched. }\end{array}$ \\
\hline 28. & $\begin{array}{l}25 \mathrm{Dec} . \\
2011\end{array}$ & \begin{tabular}{|c|} 
Madala, \\
Niger \\
state, near \\
the FCT \\
\end{tabular} & $\begin{array}{l}\text { The bombs were alleged to have been planted at the Church } \\
\text { parking lot. }\end{array}$ & $\begin{array}{l}\text { At the last count, } 45 \text { persons were killed. Some died instantly, } \\
\text { others from injuries sustained from the explosion. Over } 80 \text { others } \\
\text { were receiving treatment for various degrees of injuries. }\end{array}$ \\
\hline 29. & $\begin{array}{c}5-6 \text { Jan. } \\
2012\end{array}$ & $\begin{array}{l}\text { Gombe, } \\
\text { Gombe } \\
\text { State }\end{array}$ & $\begin{array}{l}\text { Gunmen stormed a Deeper life church in Gombe, shooting } \\
\text { indiscriminately at worshippers. The Boko Haram Islamist sect } \\
\text { claimed responsibility for the shooting. }\end{array}$ & 6 persons were reportedly killed while many others were injured. \\
\hline 30. & $\begin{array}{c}5-6 \text { Jan. } \\
2012\end{array}$ & $\begin{array}{c}\text { Mubi, } \\
\text { Adamawa } \\
\text { State }\end{array}$ & $\begin{array}{l}\text { Suspected Boko Haram militants stormed a gathering of Igbo } \\
\text { Christians and shot sporadically, killing over a dozen and } \\
\text { injuring others in apparent execution of an ultimatum given by } \\
\text { the Boko Haram Islamist sect to Southern Christians living in } \\
\text { the North to leave. }\end{array}$ & 22 persons were reportedly killed; a dozen others were injured. \\
\hline
\end{tabular}

Source: Adapted from Onuoha 2010 with additions and modifications by the author.

Any attempt by the oppressed and dominated group(s) to resist the endemic oppression embedded in the dominant culture and social institutions in a way that is so pervasive that they are often invisible and affect everyone always results in more violence and dehumanisation of the oppressed group in the society. The conflicts in Plateau State and other Northern parts of Nigeria especially in Bornu, Yobe, Kano, Kaduna, Zamfara and Taraba states are a pointer to this fact.

The Yorubas from the Southwest, the Hausa-Fulani from the North and the Ibos from the Southeast are the three major ethnic groups. These three groups have historically dominated the socio-political and economic spheres of Nigeria since independence even though the Yoruba and lbos maintained marginalisation by the Hausa-Fulani hegemony. 
National adverts, jingles, dress codes, food, language and others means of societal processes are expressed in the culture and languages of the three dominant groups. Some strategic positions/offices are a priori reserves for them President, Vice President, Senate President and Deputy Speaker of House of Representatives and Ministers of Finance, Foreign Affairs, Agriculture and Commerce. Their cultures are used to showcase Nigeria as the cultures of Nigerians. The only time the president of Nigeria is from minority ethnic group is marred with violence. A good example is the administration of the incumbent President Goodluck Jonathan which has witness the worst form of ethno-religious crisis in Nigerian history. The religious insurgency of the Boko Haram extremists has political undertones because the HausaFulani hegemony believes that it is their birth right to rule Nigeria. The clamours for power shift to the northern Nigeria were the genesis of the crisis in the north and still remain the reason for the inability of the crisis to abate. The major ethnic must be assuaged for peace to reign no matter the injustice and harm being done to the minorities in the process

The other minority ethnic and religious groups in Nigeria are so helpless and powerless to resist the domination. In the so-called unity (Federal) schools, the three languages - Hausa, Yoruba and lbo are made compulsory and imposed on other students from minority groups. The systemic oppression goes on unabated and unchallenged. This is because these oppressive forces are so deep-seated and pervasive that the oppressed believe it is part of their everyday lives and therefore normative and normal. Freire (1983) succinctly articulated the structural relationship and domination. According to her, "oppressed people become so powerless that they do not even talk about their oppression, if they reach this stage of oppression, it creates a culture wherein it is forbidden to even mention the injustices that are being committed. The oppressed are silent. Through indoctrination, the oppressed actually believe that they are naturally inferior to the ruling or dominant group. They are taught by oppressors that their inferiority is normal and a fact of life." This perhaps explains while members of the Armed Forces (Army, Navy and Air-Force) of Nigeria gladly learn Hausa as the second language next to English. This perhaps also explains why minorities in Lagos, Enugu and Kaduna easily forget their language and culture and acquire the Yoruba, Ibo and Hausa languages and cultures respectively.

\section{Implication of Social Policy Development and Social Work Practice in Nigeria}

This nature and pervasiveness of systemic and institutional oppression in Nigeria have serious implication on social policy development and social work practice in Nigeria. This call for a serious and sustained advocacy for social reformation and revolution via policy formulation geared toward the enthronement of egalitarian society or at least a society where all forms of exploitation is reduced to the barest minimum. Social Workers in Nigeria have a lot do in this respect. This call for collaboration with other professionals like the Legal profession, Human Rights activists and Non Governmental Organizations (NGOs) to fight the perpetrators of all forms of systemic oppression for whatever reasonscultural, political, religion or self aggrandisement amongst others. Social Workers should embark on massive enlightenment campaigns relevant interest groups and stakeholders for the various groups to change their negative social perceptions of other members of the Nigerian society by their fellow Nigerians for whatever reason

The government at the three tier levels in Nigeria should as a matter of urgency enact laws, policies and best practices that will reduce oppression in whatever forms and give every Nigerian equal opportunities to aspire to any position with fear and compete favourably with other Nigerians on level playing grounds. All forms of religious bigotry and extremism should be banned and made illegal. Politicians and other Nigerians who perpetrate evil and violence in the of religion should not only be punished to act deterrent to others, they should be re-socialized to know that God is the creator of all human beings and endowed humans with inalienable rights which include in the right or freedom of worship, and such right are sacrosanct and should be protected by the government with vigour and determination.

\section{Conclusion}

Oppression in any form is inhuman and violation of Fundamental Human Rights of the oppressed. It is degrading and dehumanizing and the oppressed are more or less sub-human and sometimes feel worthless and frustrated. For decades now, Nigerians of certain ethno-religions group, sex, age, physical statuses have been subjected to all forms of systemic oppression. This inhuman practices or attitude cannot continue as if it is normal and normative. There should be a national rebirth where competence and ability should determine who gets what. The systemic subtle means of oppression like state of origin, religious, sex and sexual orientation, federal character and catchment areas should be made illegal and unconstitutional. It is time to stop the system oppression and domination of other ethnic groups by the dominant ethnic nationalities (Ibo, Yoruba and Hausa-Fulani) groups. This may address the issue of retrogressive governance and comatose economy being managed by mediocre leaders imposed on Nigeria by systemic oppressive forces of ethnic politics and federal character configuration. It is time to stop the denigration of potentials, expertise and 
competency at the instance of federal character or religious bigotry. Thus as the constitution of the Federal Republic of Nigeria enunciates, every Nigerian should be treated equally and also should have equal access to the resources of Nigeria.

\section{References}

Agwu, C.O.T., (2009). Religious conflicts in Kano and Kaduna States. In Ikejiani-Clarke, Mirian ed Peace studies and conflicts resolution in Nigeria: A reader, Ibadan, Spectrum Books, pp. 518-531.

Ajir, J.C., (2002). Women empowerment and work: The challenges of the 21st century. Abort Press, Abuja.

Barker, R.C., (2003). The Social Work Dictionary (5th ed.) Washington DC, NASW Press.

Barone, C., (1995). The personal and social dynamics of oppression, working paper, Dickson College, Carlisle P.A.

Barone, C., (1998). Extending Our Analysis of Class Oppression: Bringing Classism more fully into the Race and Gender Picture. Dickson College, Carlisle P.A.

Bell, H., (1994). Outlaw Culture: Resisting representations. New York, Routledge.

Burchadt, T. Grand, T. and Plachood, D., (1999). Social Exclusion in Britain 1991 - 1995, Journal of Social Policy and Administration Vol. 33 no 3 pg 227-44

Charton, J.I., (1998). Nothing about Us without Us: Disability Oppression and Empowerment. Berkeley: University of California Press.

Cheney, C. Latrance, J. and Quinteros, T., (2006). Tri-Country Domestic and Sexual Violence Intervention Network Anti Oppressive Training for Trainers. Institutionalised oppression tool for diversity. www.actforaction.org (accessed 12/2/13).

Clarice, F., (1992), Women Battering on Navajo Reservation. Journal of International Review of Victimology vol 2 no 2 137-463.

Commission of the European Communities (1993). Background Report: Social Exclusion-Poverty and Social Problems in the European community. Luxembourg office for official publications of the European communities.

Daus, K.E., (2002). Expanding the theoretical understanding of oppression. Alexandra, Vac Council on Social Work Education.

Davis, A., (1990). Women, culture, and politics. New York. Vintage Books.

Deutsch, M., (2006). A framework for thinking about oppression and its change: Social Justice Research 19(1): 7-41.

Ezechukwu, U., (2000). Is Nigeria breaking up? West Africa News, Lagos.

Freire, P., (1981). Pedagogy of the oppressed: New-York. Continuum Publishers.

Geddes \& Grosset (2010). Webster Universal Dictionary \& Thesaurus. Glasgow

Gil, D.G., (1994). Confronting Social Injustices and Oppression in F.G. Reamer (Ed.): The Foundations of Social Work Knowledge. New York, Columbia.

Gofwen, R.I., (2004). Religious conflicts in northern Nigeria and nation buildings: The throes of two decades 1980-2000. Kaduna, Human Right Monitor.

Hill, C.P., (1990). Black feminist thought, consciousness and the politics of empowerment. New York, Routledge.

Iwara, U.E., (2006). Religious violence in Nigeria: Causes and consequences. Sophia: An African Journal of Philosophy 8(2) pp 153-157.

Johnson, A.G., (2000a). Privilege, Power and Difference. Boston: McGraw-Hill.

Johnson, A.G., (2000b). The Blackwell Dictionary of Sociology: A user's guide to sociological language (2nd ed) Oxford (England) Malden M.A. Blackwell Publishers.

Karen, A., (1991). Chain her by one foot: The Subjugation of Women in Seventeenth Century. New York, Routledge.

Kwaja, C.M.A., (2009). Strategies for Rebuilding State Capacity to Manage Ethnic and Religious Conflicts in Nigeria. The Journal of Pan African Studies 3(3) pp. 105-115.

Little, A., (2011). Unveiling Oppression in Northern Nigeria. Available at msmagazine.com/ blog/2011/03/08unveiling-oppression-in-northernnigerial. (Accessed on 12/11/2013)

Madanipour, A.; Cara, G. and Allon, J. (eds) Social Exclusion in European Cities: Processes Experiences and Responses. Jessical Kingsley, London.

Okojie, C.E.E., (2011): Achieving gender equality and women's empowerment in Nigeria: Should women wait in the hope or expectation? Inaugural lecture series 120, University of Benin Press, Benin-City

Omotosho, A.O., (2003). Religious violence in Nigeria: The causes and solutions. An Islamic Perspective. Swidish Missiological Theme pp 15-31.

Onuoha, F.C., (2010). The State and Management of Religious Violence in Nigeria: A case of July 2009 Boko Haram revolt. PhD seminar paper presented to the Department of Political Science, University of Nigeria, Nsukka, Nigeria.

Percy-Smith, J.,(2000). The Contour of Social Exclusion in Janie Percy-Smith (ed.) Policy Responses to Social Exclusion: Toward Inclusion? Open University Press, Philadelphia.

Roc, A., (1977). Of women, Born Motherhood as Experience and Institution. Virago Press, London.

Salawu, B., (2010). Ethno-religious conflicts in Nigeria: Causal analysis and proposals for new management strategies: European Journal of Social Sciences. 13(3) pg 345-353.

Sanusi, A., (2009). Religious-Base Violence and National Security in Nigeria: Case studies of Kaduna State and the Taliban activities in Kebbi State. Master of military arts and science thesis, US Army Command and General Staff College.

Stage Left Productions Workshop for Canada World Youth: Oppression and Privilege Framework www.stageleft.org: Using the arts to affect personal and social transformation. (Accessed on 12/3/2013)

Udegbe, C., (2013). Blame not ethnicity for Nigeria failures, Vanguard newspapers, Nov. $7^{\text {th }} 2013, \mathrm{pg} 81$.

Yamato, G., (1995). "Something about the Subject Make it Hard to Name" Race, Class and Gender: An Anthology. Margaret. Wadsworth Pub Co.

Young, T.M., (1994). Punishment, Treatment, Empowerment: Three Approaches to Policy for Pregnant Addicts. Feminist Studies 20(1): 33-57. 